\title{
Evaluation of anticonvulsant activity of angiotensin receptor antagonists in an animal model
}

\author{
Asha D. Jadhav ${ }^{1 *}$, Rakesh R. Jadhav², Sudhir L. Padwal' ${ }^{2}$, Swapnil S. Jadhav, \\ Anand S. Kale ${ }^{2}$, Prakashchandra R. Gade ${ }^{1}$
}

\begin{abstract}
${ }^{1}$ Department of Pharmacology, Dr. V. V. P. Medical College and Hospital, Ahmednagar, Maharashtra, India
${ }^{2}$ Department of Pharmacology, S. R. T. R. Hospital and Medical College Ambajogai. Maharashtra, India

${ }^{3}$ Department of Pharmacology, Govt. Medical College, Miraj, Maharashtra, India
\end{abstract}

Received: 08 September 2020

Accepted: 07 October 2020

\section{*Correspondence:}

Dr. Asha D. Jadhav,

Email: drashajadhav12@gmail.com

Copyright: (C) the author(s), publisher and licensee Medip Academy. This is an open-access article distributed under the terms of the Creative Commons Attribution Non-Commercial License, which permits unrestricted non-commercial use, distribution, and reproduction in any medium, provided the original work is properly cited.

\begin{abstract}
Background: Epilepsy is common chronic disorder in clinical practice and there was some studies which shows brain renin angiotensin system may be involved in upregulation of seizures hence present study was planned to investigate whether angiotensin II AT1 receptor antagonists possess anticonvulsant activity in experimental animals.

Methods: The anticonvulsant activity of angiotensin receptor antagonists, losartan $(50 \mathrm{mg} / \mathrm{kg})$, telmisartan $(30 \mathrm{mg} / \mathrm{kg})$ and candesartan $(20 \mathrm{mg} / \mathrm{kg})$, were administered intraperitoneally to the mice and evaluated by using maximum electroshock (MES) and pentylenetetrazol induced seizures (PTZ) seizure methods. The standard was taken as phenytoin for MES and diazepam for PTZ method. Motor impairment of performance was assessed by the inverted screen test and spontaneous motor activity with digital actophotometer.

Results: Losartan demonstrated the anticonvulsant efficacy in MES and PTZ models. Telmisartan and candesartan have anticonvulsant activity in MES induced seizures, but did not show protection against pentylenetetrazol induced seizures. Losartan at dose $50 \mathrm{mg} / \mathrm{kg}$ prolonged the mean latency to convulsion $(\mathrm{p}<0.01)$ and mean number of convulsions also significantly reduced $(\mathrm{p}<0.05)$ convulsions in the mice. Telmisartan and candesartan at dose $30 \mathrm{mg} / \mathrm{kg}$ and $20 \mathrm{mg} / \mathrm{kg}$ respectively showed significant prolongation in mean latency to convulsion $(\mathrm{p}<0.05)$. None of the test drugs i.e. angiotensin receptor antagonists showed significant motor impairment.

Conclusions: Angiotensin receptor antagonists: losartan, telmisartan and candesartan had showed anticonvulsant activity in PTZ and MES seizure methods. The exact mechanism of action of their anticonvulsant action not precisely known and hence there is more studies need to test it in various other animal anticonvulsant models.
\end{abstract}

Keywords: Maximal electroshock, Pentylenetetrazol, Losartan, Telmisartan, Renin angiotensin system

\section{INTRODUCTION}

Epilepsy is the commonest neurological condition contributing $0.5-1 \%$ global burden of disease with a cumulative lifetime incidence of approximately $3 \% .{ }^{1}$ It is a chronic disorder characterized by recurrent and unprovoked seizures, which may vary from a brief lapse of attention or muscle jerks, to severe and prolonged convulsions. Seizures are due to abnormal excessive and synchronous neuronal activity in the brain caused by a disruption of the delicate balance between excitation and inhibition. Epilepsy can be acquired as a result of an insult to the brain such as trauma, infection, stroke or a tumour and can result from a genetic mutation in one or more of the ion channels or neurotransmitter genes or proteins that control brain excitability. 
Epilepsy not only affects brain physiology but also causes serious effects concerning physical, behavioural, cognitive and psychosocial aspects of life. ${ }^{2}$ Main objective in the treatment of epilepsy is to attain seizure-freedom without producing antiepileptic drug toxicity and affecting normal brain function. Such ideal antiepileptic drug may mean that seizure control cannot be absolute. Therefore the usual approach towards antiepileptic drug therapy is to maximize seizure control while minimizing adverse drug effects. Despite introduction of several new antiepileptic drugs, $25-30 \%$ of the patients with epilepsy continue to live with uncontrolled seizures. ${ }^{3-4}$ This could be due to incomplete understanding of etiopathology and limitation of available drugs in terms of adverse effects and susceptibility to clinically important drug interactions. ${ }^{5}$ Drug resistant epilepsy can be due to idiopathic epileptic syndromes and complex partial seizures. ${ }^{6}$

Drug interactions are significantly important while treating the epilepsy in special populations such as children, women during pregnancy and elderly people. Therefore the search for potentially more effective and a better tolerated agent is continuing.

Recent evidence suggests that the renin angiotensin system (RAS) exists in brain and is associated with the regulation of body water balance, thirst, blood pressure maintenance, vasopressin release, stress memory and depression. Additionally this system has been implicated in regulation of cerebral blood flow, cerebroprotection, stress and seizures. ${ }^{7}$ Angiotensin II (Ang-II) is key peptide hormone in RAS and exerts its actions through AT1and AT2 receptors in different areas of brain.

It was reported that angiotensin II increases the seizure threshold in pentylenetetrazole induced seizure test in mice which was blocked by losartan. Suggesting Ang-II peptide has an anticonvulsant activity mediated through an AT1 receptor. It was also studied an up-regulation of AT1 and AT2 receptors in the cortex and hippocampal area of patients with temporal lobe epilepsy with mesial temporal sclerosis supporting renin angiotensin system involvement in the pathology. It was also studied an increased concentration of angiotensin II in the hippocampus of rats in the chronic phase of pilocarpine epilepsy model which suggests the involvement of brain renin angiotensin system in seizure susceptibility. ${ }^{8}$

These experimental and clinical studies also suggest that RAS may play a role in pathology of seizure development.

It is well known that hypertension is associated with the activated RAS. Also, study conducted by Gaitatzis et al in a clinical study reported that cardiovascular complications related to hypertension occurred more frequently in people with epilepsy. ${ }^{9}$ So, it may be beneficial to choose an optimal drug that will target both these conditions. Angiotensin AT1 receptor antagonists, are widely used in clinical practice for treatment of hypertension, congestive heart failure and diabetic nephropathy.
There were reports of angiotensin II receptor antagonists like losartan and telmisartan and an angiotensin converting enzyme (ACE) inhibitor enalapril having anticonvulsant effect in animal models of epilepsy. ${ }^{10}$

These results suggest that centrally acting drugs that target the brain renin angiotensin system have possible anticonvulsant action and may be an addition to the existing drugs in the management of epileptic patients. Angiotensin receptor antagonist i.e. losartan and telmisartan have been shown to cross the blood brain barrier and selectively inhibit angiotensin AT1 receptor in the brain after systemic administration. ${ }^{11}$

Candesartan is reported to cross blood brain barrier and act on brain RAS through AT1 receptor antagonism. ${ }^{12}$ However despite best search of references for effect of candesartan on experimental models of epilepsy we could not find any one.

In view of these findings, the present study was planned to investigate whether angiotensin II AT1 receptor antagonists (losartan, telmisartan and candesartan) possess anticonvulsant activity in experimental animals.

\section{METHODS}

\section{Experimental animals}

Swiss albino mice of either sex for the study were procured from the animal house, of our college. The animals were housed under standard conditions with free access to food and water. Mice weighing 20-25 g were randomly allocated to different groups of six and placed in suitable cages. The mice were allowed to adjust to the laboratory conditions such as light, temperature and noise before being subjected to the experiments. All the experiments were carried out at the same time of the day i.e. between 10 am to $5 \mathrm{pm}$ to minimize circadian influence on seizure susceptibility.

The study was conducted after the approval of the institutional animal ethics committee (approval letter number 378/12 Dated14/12/2012), which is an approved body by the committee for the purpose of control and supervision of experiments on animals (CPCSEA).

\section{Drugs and chemicals}

Test drug losartan (source: Cipla ltd, Mumbai) was dissolved in normal saline; telmisartan (source: Medley pharmaceuticals, Jammu) and candesartan (source: Ranbaxy laboratories ltd, Haryana) were suspended in $1 \%$ sodium carboxy methyl cellulose (CMC) in saline. CMC was obtained as gift from Medley pharmaceuticals, Mumbai. Pentylenetetrazol was purchased from Jinedra scientifics chemicals ltd., Jalgaon (Maharashtra). Phenytoin and diazepam were obtained from commercial sources and were dissolved in normal saline. 
All drugs were administered intraperitoneally (i.p.) to the mice.

\section{Equipments}

Electroconvulsiometer with ear-clip electrodes, digital actophotometer, wire mesh, stop watch.

\section{Methods}

It included the methods used in evaluation of anticonvulsant activity.

\section{Maximal electroshock (MES) method ${ }^{6}$}

For this method the mice were arranged in 5 groups of 6 mice in each group. The mice were injected the drugs i.p. 30 minutes prior to subjecting them to electroshock. The electroconvulsiometer was set to deliver alternating current of $50 \mathrm{~mA}$ for duration of $0.2 \mathrm{sec}$ through ear electrodes. The 2 ear clip electrodes of the electroconvulsiometer were applied one to each ear after moistening the ears with normal saline. The mice were then stimulated transauricularly and observed. The resultant seizure passes through various phases: phase of tonic limb flexion, tonic limb extension, clonus, and postictal depression followed by recovery or death. The occurrence of a tonic hind limb extensor was taken as a positive response for MES. Abolition of tonic hind limb extension to an angle with the trunk greater than 90 degree was taken as protective against MES seizures. The following parameters were noted: patency to convulsion, duration of tonic hind limb extension (THE), and percentage seizure protection and the mortality.

\section{Pentylenetetrazole (PTZ) method ${ }^{6}$}

For this method the mice were arranged in 5 groups of 6 mice each. The drugs were injected i.p. to mice 30 minutes prior to subjecting them to chemoconvulsion by pentylenetetrazole (PTZ). PTZ dissolved in normal saline was given i.p.in a dose of $75 \mathrm{mg} / \mathrm{kg}$ in volume not exceeding $0.01 \mathrm{ml} / \mathrm{gm}$ of body weight. Animals are observed for a 30 minutes for the occurence of seizures. The occurrence of tonic clonus for more than 5 seconds was taken as a positive seizure response and abolition of tonic clonus was considered as protection against PTZ seizures. The parameters noted were: leizure latency (time for onset of seizure), duration of tonic clonus, and percentage of seizure protection and mortality.

\section{Tests for neurological deficit ${ }^{13}$}

\section{Inverted screen test}

Inverted screen test is a useful performance test for assessing motor function decrement by test drugs. The screen test apparatus was very similar to that described by Coughenour. ${ }^{13}$ Basically it consisted of six rectangular wire mesh screens $(9.5 \times 13 \mathrm{~cm})$ horizontally mounted on a single metal rod. The mice were placed individually on top of the screens. The apparatus was slowly inverted so that the mice were suspended upside down on the bottom of the screens. During the next 2 minutes, the animals were observed for their ability to climb to the top of the inverted screen. After 2 minutes, animals were assigned to one of two response groups: animals which successfully climbed to the top of the inverted screen were assigned a "passing" score, or animals which either fell from the screen or held onto the screen in an inverted position were assigned a "failing" score.

\section{Spontaneous motor activity}

The spontaneous locomotor activity of each mouse was recorded individually for 5 minutes using digital actophotometer, equipped with six infrared light sources and photocells. The movement of animal interrupts a beam of light falling on photocells at which count was recorded and displayed digitally. Actophotometer calibration was done prior to experimentation. Each mouse was placed separately in the activity cage for 5 minutes and the basal activity score $(0 \mathrm{~min})$ of each mouse was noted. The tested compounds were administered i.p. and the activity scores for 5 min were noted after 30 minutes, 60 minutes and 90 minutes.

\section{Statistical analysis}

The data were expressed as mean \pm standard error of mean (SEM). The latency to convulsion, duration of convulsions and number of convulsions were analyzed by one way analysis of variance (ANOVA) followed by post-hoc Tukey's test for comparison between multiple groups. The seizure protection and percentage mortality were analyzed by Fisher's exact test. The 'p' value less than 0.05 was considered as statistically significant. The data was analyzed by using "Graph Pad prism, version 5.00 for Windows, Graph Pad software, San Diego California USA, www.graphpad.com."

\section{RESULTS}

The anticonvulsant effect was observed in test groups losartan, telmisartan and candesartan groups. Among these groups losartan group shows highly significant $(\mathrm{p}<0.01)$ increase in latency to convulsion as compared to control group and telmisartan and candesartan also had significantly prolonged latency to onset of convulsion in maximal electroshock induced seizures method $(\mathrm{p}<0.05)$. The duration of tonic hind limb extension phase was lower in test group as compared with control group however, it was not statistically significant.

The seizure protection was seen in phenytoin group only. The percentage mortality was seen less in losartan and telmisartan group when compared to the control, but was statistically not significant. Candesartan groups did not show any reduction in mortality as compared to control group. 
There was a complete abolition of tonic hind limb extension phase in phenytoin group. Hence latency to onset of convulsion, duration of convulsion and mortality of test drugs cannot compare with phenytoin.

Table 2 shows effect of drugs on PTZ induced seizure method. The anticonvulsant effect was observed in losartan groups. Losartan prolonged the latency to convulsions when compared with the control group $(\mathrm{p}<0.05)$. Telmisartan and candesartan also prolonged the latency to convulsion as compared to the control group, but this prolongation was not statistically significant.

Losartan significantly reduced the mean number of clonic convulsions when compared to control group $(p<0.05)$. There was no statistically significant reduction in the number of clonic convulsions in telmisartan and candesartan treated group.

There was no statistically significant reduction in duration of clonic convulsions in all the three study drugs when compared to control group.

Losartan prevented the occurrence of seizures in one out of six mice in the group, offering a seizure protection of $16.667 \%$, but it was statistically not significant when compared to control group. Candesartan and telmisartan did not show any seizure protection.

There was no statistically significant reduction in mortality in any of the three study drugs when compared with control group. Diazepam showed $100 \%$ seizure protection and abolished the clonic phase of convulsions.

Hence, latency to onset of convulsion, duration of convulsion, number of convulsion and mortality of test drugs cannot compare with diazepam.

The tendency to cause motor impairment by the drugs is evaluated using inverted screen test the result was shown in Table 3. Six out of six mice failed to climb to the top with inverted screen test in both phenytoin and diazepam group. It was statistically significant $(\mathrm{p}<0.01)$ when compared to control group. All the mice were able to climb the inverted screen in losartan, telmisartan and candesartan group showing no motor impairment.

Table 4 shows that the basal counts of spontaneous activities were comparable in all the six groups in spontaneous motor activity test by using digital actophotometer.

There was a significant reduction in motor activities in phenytoin groups at 30 minutes $(\mathrm{p}<0.01), 60$ minutes and 90 minutes $(\mathrm{p}<0.001)$ when compared to the control group. Also there was a significant reduction in motor activities in diazepam groups at 30 minutes, 60 minutes and 90 minutes $(\mathrm{p}<0.001)$ when compared to the control group.

The activities of losartan, telmisartan and candesartan groups were comparable with control group at all intervals and were not statistically significant.

Table 1: Effect of drugs on maximal electroshock induced seizures in albino mice.

\begin{tabular}{|llllll} 
Drug & $\begin{array}{l}\text { Dose } \\
(\mathrm{mg} / \mathrm{kg})\end{array}$ & $\begin{array}{l}\text { Latency to convulse } \\
(\mathrm{sec}) \text { mean } \pm \text { SEM }\end{array}$ & $\begin{array}{l}\text { Duration of THE } \\
(\mathrm{sec}) \text { mean } \pm \text { SEM }\end{array}$ & $\begin{array}{l}\text { Seizure } \\
\text { protection } \%\end{array}$ & $\begin{array}{l}\text { Mortality } \\
\%\end{array}$ \\
\hline Control (normal saline) & 0.2 & $1.473 \pm 0.1988$ & $9.953 \pm 0.5644$ & 0 & 50 \\
\hline Phenytoin & 100 & - & - & $100^{\# \#}$ & 0 \\
\hline Losartan & 50 & $2.178 \pm 0.1392^{*}$ & $13.38 \pm 0.3558^{*}$ & 0 & 33.33 \\
\hline Telmisartan & 30 & $2.125 \pm 0.0781^{*}$ & $13.81 \pm 0.7509^{*}$ & 0 & 33.33 \\
\hline Candesartan & 20 & $1.652 \pm 0.2025$ & $12.72 \pm 0.1029$ & 0 & 50
\end{tabular}

*p $<0.05$ when compared to control group by post hoc Tukey's test, $\# \# \mathrm{p}<0.01$ when compared to control group by Fisher's exact test, i.p=intraperitoneal, THE=tonic hind limb extension, $\mathrm{SEM}=$ standard error of mean, $\mathrm{n}=6$

Table 2: Effect of drugs on pentylenetetrazole induced convulsions in mice.

\begin{tabular}{|lllllll|}
$\begin{array}{l}\text { Drugs } \\
\text { (n=6 animals) }\end{array}$ & $\begin{array}{l}\text { Dose } \\
(\mathbf{m g} / \mathrm{kg})\end{array}$ & $\begin{array}{l}\text { Latency to } \\
\text { convulse }(\mathrm{sec})\end{array}$ & $\begin{array}{l}\text { Duration of clonic } \\
\text { convulsions }\end{array}$ & $\begin{array}{l}\text { Number of } \\
\text { convulsions }\end{array}$ & $\begin{array}{l}\text { Seizure } \\
\text { protection } \%\end{array}$ & $\begin{array}{l}\text { Mortality } \\
\%\end{array}$ \\
$\begin{array}{l}\text { Control } \\
\text { (normal saline) }\end{array}$ & 0.2 & $31.43 \pm 3.248$ & $26.28 \pm 1.608$ & $3.500 \pm 0.2887$ & 0 & 100 \\
\hline Diazepam & 2.5 & -- & -- & -- & $100^{\# \#}$ & $0^{\# \#}$ \\
\hline Losartan & 50 & $130.90 \pm 9.083 * *$ & $25.09 \pm 2.552$ & $1.800 \pm 0.200 *$ & 16.667 & 50 \\
\hline Telmisartan & 30 & $80.54 \pm 9.076$ & $23.57 \pm 2.87$ & $2.667 \pm 0.6146$ & 0 & 33.33 \\
\hline Candesartan & 20 & $145.5 \pm 10.09 * * *$ & $20.38 \pm 3.804$ & 1.200 & 0 & 33.33 \\
\hline
\end{tabular}

Values are in mean $\pm \mathrm{SEM}, * \mathrm{p}<0.05$ when compared to control group, $* * \mathrm{p}<0.01$ when compared to control group, $* * * \mathrm{p}<0.001$ when compared to control group, \#\#p<0.01 when compared to control group by Fishers exact test 
Table 3: Effect of drugs on inverted screen test in albino mice.

\begin{tabular}{|c|c|c|c|c|}
\hline Drug & Dose (mg/kg) & Number of mice falling & Mice falling \% & Mice climbing \% \\
\hline Normal saline & 0.2 & $0 / 6$ & 0 & 100 \\
\hline Phenytoin & 100 & $6 / 6$ & $100 * *$ & 0 \\
\hline Diazepam & 2.5 & $6 / 6$ & $100 * *$ & 0 \\
\hline Losartan & 50 & $0 / 6$ & 0 & 100 \\
\hline Telmisartan & 30 & $0 / 6$ & 0 & 100 \\
\hline Candesartan & 20 & $0 / 6$ & 0 & 100 \\
\hline
\end{tabular}

**p $<0.01$ as compared to control, $\mathrm{n}=6$ in each group

Table 4: Effect of drugs (i.p.) on locomotor activity of albino mice at different time interval.

\begin{tabular}{|llllll|}
\hline Drug $(\mathbf{n = 6}$ animals) & Dose $(\mathbf{m g} / \mathrm{kg})$ & $\mathbf{0}$ min & $\mathbf{3 0} \mathbf{m i n}$ & $\mathbf{6 0} \mathbf{m i n}$ & $\mathbf{9 0} \mathbf{m i n}$ \\
\hline Control (normal saline) & 0.2 & $178.3 \pm 9.986$ & $161.5 \pm 10.27$ & $167.5 \pm 6.764$ & $174.3 \pm 3.705$ \\
\hline Phenytoin & 100 & $180.5 \pm 11.79$ & $106 \pm 8.031 * *$ & $81.25 \pm 3.75 * * *$ & $79.5 \pm 9.106 * * *$ \\
\hline Diazepam & 2.5 & $191 \pm 2.646$ & $73.75 \pm 14.69 * * *$ & $72.75 \pm 15.6 * * *$ & $54 \pm 6.069 * * *$ \\
\hline Losartan & 50 & $169 \pm 10.47$ & $171.5 \pm 8.665$ & $169.3 \pm 7.443$ & $155.3 \pm 5.186$ \\
\hline Telmisartan & 30 & $201.5 \pm 9.665$ & $192.8 \pm 7.064$ & $166.8 \pm 15.41$ & $170.8 \pm 5.266$ \\
\hline Candesartan & 20 & $207 \pm 3.784$ & $190 \pm 7.528$ & $168 \pm 9.921$ & $169.5 \pm 1.555$ \\
\hline
\end{tabular}

Values are in mean \pm SEM, $* \mathrm{p}<0.05$ when compared to control, $* * \mathrm{p}<0.01$ when compared to control, $* * * \mathrm{p}<0.001$ when compared to control

\section{DISCUSSION}

The major progress in understanding the mechanisms associated with epileptiform events and anticonvulsant activity of antiepileptic drugs have led to an improvement in the treatment of human epilepsies. However, approximately $25-30 \%$ of epileptic patients are refractory to standard therapy. ${ }^{3-4}$ This could be due to incomplete understanding of etiopathology and adverse effects of available antiepileptic drugs. ${ }^{5}$

Antiepileptic drugs mainly act by modulation of ion channels or neurotransmitters. The specific mechanism (s) of action of an antiepileptic drug can increase the risk of particular types of adverse events. Specifically, antiepileptic drugs with traditional GABAergic mechanisms have the most detrimental effects on cognitive function, possibly because they impair attention. Conversely, drugs with the predominant effects at $\mathrm{Na}+$ channels appear to have minimal impact on cognition. Also levetiracetam, with its nonconventional GABAergic and $\mathrm{Ca}^{2+}$ channel effects, has shown positive cognitive effects in animal studies. Antiglutamatergic drugs have the potential to be a double-edged sword because they not only provide neuroprotection in addition to their antiseizure effects but also can interfere with consolidation of learning and memory. ${ }^{14}$

Though impairment of cognition and psychomotor activity are considered to be mild to moderate with most antiepileptic drugs, their impact may be substantial on quality of life particularly when central functions are involved such as learning in children and young patients or driving capabilities in adults. ${ }^{14}$

In present study impairment of motor performance was assessed by the inverted screen test and spontaneous motor activity with digital actophotometer. In inverted screen test the mice were observed for ability to climb the inverted screen while digital actophotometer was used to count spontaneous motor activity. Drugs with sedative or ataxic properties produce dose dependent failure to climb the inverted screen as well as they decreased motor activity measured by the actophotometer. In our study, none of the test drugs i.e. AT1 receptor antagonists showed significant motor impairment.

Although there are a large number of models that could be used to screen for anticonvulsant activity, the MES and the PTZ model remain the "gold standards". 6

In the present study anticonvulsant effects of angiotensin receptor antagonist; losartan, telmisartan and candesartan were evaluated with MES and PTZ method.

Losartan demonstrated the anticonvulsant efficacy in MES induced seizures and pentylenetetrazol induced seizures. Telmisartan and candesartan have anticonvulsant activity in MES induced seizures, but did not show protection against PTZ induced seizures.

Losartan at dose $50 \mathrm{mg} / \mathrm{kg}$ prolonged the mean latency to convulsion which was statistically highly significant $(\mathrm{p}<0.01)$.

Telmisartan and candesartan at dose $30 \mathrm{mg} / \mathrm{kg}$ and 20 $\mathrm{mg} / \mathrm{kg}$ respectively showed significant prolongation in mean latency to convulsion $(\mathrm{p}<0.05)$. The mean duration of tonic hind limb extension decreased in test groups compared to the control group however, it was not statistically significant.

PTZ test is widely used as a standard model for absence (petitmal) epilepsy. In this our study losartan had 
antiseizure activity in albino mice. Losartan at $50 \mathrm{mg} / \mathrm{kg}$ significantly $(\mathrm{p}<0.05)$ prolonged the mean latency to convulsions when given intraperitoneally. It also significantly reduced $(\mathrm{p}<0.05)$ the mean number of convulsions in the mice.

Telmisartan and candesartan did not show significant protection against the PTZ induced seizure.

Also, the test drugs did not to show significant reduction in duration of convulsions and mortality in comparison to control.

Standard antiepileptic drugs phenytoin and diazepam showed $100 \%$ seizure protection and no mortality in MES and PTZ method respectively.

Test drugs did not showed significant seizure protection and reduction in mortality compared to control group in both MES and PTZ seizure models.

At present, anticonvulsant mechanism (s) of angiotensin AT1 receptor antagonists is not precisely known. Possible mechanism of anticonvulsant action of angiotensin receptor antagonist could be due to blockade of the brain renin angiotensin system by these drugs. The functional inhibition of the renin angiotensin system in the brain by losartan may significantly impair the triggering and maintenance of seizure. It is possible that they may act by modulation of GABAergic and glutamatergic neurotransmission. ${ }^{11}$

It was reported that the enhancement of GABAergic transmission protects against some types of seizures including maximal electroshock induced convulsions and PTZ kindling model of epilepsy. ${ }^{15}$ The possible anticonvulsant action of losartan and telmisartan might be related to their interaction between Ang-II AT1 receptors with GABA and GABA-benzodiazepine receptorionophore complex. Ang-II binding sites are localized in some brain structures, i.e. septum, substantia nigra, midbrain, hypothalamus, medulla, etc. involved in seizure susceptibility. The GABA receptor density in these structures is also high. ${ }^{15}$

Angiotensin receptor antagonists enhance the anticonvulsant action of Ang-II and Ang-IV by activation of other ligands. It was supported by findings of Georgiev et al study that an AT1 receptor antagonist. ${ }^{15}$ Losartan also exerted anticonvulsant action similar to the action of AngII, an AT1 receptor agonist, on PTZ-kindled seizures. AngIV is one of the metabolites which have demonstrated an anticonvulsant activity against pilocarpine-induced seizures via dopamine and GABA release in the brain. ${ }^{16}$

ARBs have anti-inflammatory action by antagonizing the Ang-II mediated inflammation in addition to PPAR- $\gamma$ agonist action. It was observed that up-regulation of AT1 and AT2 receptors in the cortex and hippocampal formation in patients of temporal lobe epilepsy with mesial temporal sclerosis supporting involvement of renin angiotensin system in pathology of inflammation and epilepsy. ${ }^{8}$ Benicky et al reported activation of angiotensin receptors by Ang-II promotes inflammatory response by inducing oxidative stress, NADPH oxidase and nuclear factor kappa-light chain-enhancer of activated B cell (NF$\kappa \mathrm{B})$ activation and along with production of several cytokines and adhesion molecules. ${ }^{17}$ In addition, many experimental studies suggest that $\mathrm{NF}-\kappa \mathrm{B}$ and cytokines participate in the neuronal excitability and/or in glial scar formation in epilepsy. Being an activator of PPAR- $\gamma$ as well as blocking the action of Ang-II; angiotensin receptor antagonist exerts anti-inflammatory actions. ${ }^{18}$ Antiinflammatory activity angiotensin receptor antagonist could also contribute to antiepileptic action.

\section{CONCLUSION}

In the present study angiotensin receptor antagonists found to have anticonvulsant activity in MES and PTZ seizure models. The review of mechanisms of action of their anticonvulsant action appears to be diverse, not precisely known. The finding of our study corroborates with those of other authors. However, there is dirth of information, on this subject. There are early studies and some of them are mutually contradictory. To establish the role of drugs acting on the renin angiotensin system in therapy of seizure disorders more studies are required.

\section{Funding: No funding sources \\ Conflict of interest: None declared \\ Ethical approval: The study was approved by the Institutional Ethics Committee}

\section{REFERENCES}

1. Srinivas HV. Epilepsy: The future scenario. Ann Indian Acad Neurol. 2010;13:2-5.

2. Dudra-Jastrzebska M, Andres-Mach MM, Luszczki JJ, Czuczwar SJ. Mood disorders in patients with epilepsy. Pharmacol Rep. 2007;59:369-78.

3. Bialer M, White HS. Key factors in the discovery and development of new antiepileptic drugs. Nat Rev Drug Discov. 2010;9:68-82.

4. Perucca E, Tomson T. The pharmacological treatment of epilepsy in adults. Lancet Neurol. 2011;10:446-56.

5. Fattore C, Perucca E. Novel Medications for Epilepsy. Drugs. 2011;71:2151-78.

6. Loscher W. Critical review of current animal models of seizures and epilepsy used in the discovery and development of new antiepileptic drugs. Seizure. 2011;20:359-68.

7. Wright JW, Harding JW. Brain renin-angiotensin--a new look at an old system. Prog Neurobiol. 2011;95:49-67.

8. Gouveia TL, Frangiotti MI, de Brito JM, de Castro Neto EF, Sakata MM, Febba AC, et al. The levels of renin-angiotensin related components are modified in the hippocampus of rats submitted to pilocarpine model of epilepsy. Neurochem Int. 2012;61:54-62. 
9. Gaitatzis A, Carroll K, Majeed A, W Sander J. The epidemiology of the comorbidity of epilepsy in the general population. Epilepsia. 2004;45:1613-22.

10. Lukawski K, Janowska A, Jakubus T, Czuczwar S. Interactions between angiotensin AT1 receptor antagonists and second-generation antiepileptic drugs in the test of maximal electroshock. Fundam Clin Pharmacol. 2014;28:277-83.

11. Pereira MG, Becari C, Oliveira JA, Salgado MC, Garcia-Cairasco N, Costa-Neto CM. Inhibition of the renin-angiotensin system prevents seizures in a rat model of epilepsy. Clin Sci (Lond). 2010;119:477-82.

12. Pelisch N, Hosomi N, Ueno M, Masugata H, Murao $\mathrm{K}$, Hitomi H, et al. Systemic candesartan reduces brain angiotensin II via down regulation of brain reninangiotensin system. Hypertens Res. 2010;33:161-4.

13. Coughenour LL, Mclean JR, Parker RB. A new device for the rapid measurement of impaired motor function in mice. Pharmacol Biochem Behav. 1977;6:351-3.

14. Sankar R, Holmes GL. Mechanisms of action for the commonly used antiepileptic drugs: relevance to antiepileptic drug-associated neurobehavioral adverse effects. J Child Neurol. 2004;19:6-14.
15. Tchekalarova J, Georgiev VP. Adenosine-angiotensin II interactions in pentylenetetrazol seizure threshold in mice. J Physiol Paris. 1999;93:191-7.

16. Stragier B, Clinckers R, Meurs A, De Bundel D, Sarre $\mathrm{S}$, Ebinger $\mathrm{G}$, et al. Involvement of the somatostatin-2 receptor in the anti-convulsant effect of angiotensin IV against pilocarpine-induced limbic seizures in rats. $\mathbf{J}$ Neurochem. 2006;98:1100-13.

17. Benicky J, Sanchez-Lemus E, Honda M, Pang T, Orecna M, Wang J, et al. Angiotensin II AT1 receptor blockade ameliorates brain inflammation. Neuropsychopharmacology. 2011;36:857-70.

18. Ferder L, Inserra F, Martínez-Maldonado M. Inflammation and the metabolic syndrome: role of angiotensin II and oxidative stress. Curr Hypertens Rep. 2006;8:191-8.

Cite this article as: Jadhav AD, Jadhav RR, Padwal SL, Jadhav SS, Kale AS, Gade PR. Evaluation of anticonvulsant activity of angiotensin receptor antagonists in an animal model. Int J Basic Clin Pharmacol 2021;10:29-35. 